\title{
Car emissions are EPA's problem
}

\section{In a major victory for} environmentalists, the US Supreme Court this week ruled that the federal government must regulate carbon dioxide emitted from cars and trucks.

In a strongly worded opinion issued on 2 April, the justices brushed aside insistence from the Environmental Protection Agency (EPA) that it did not have the authority under the Clean Air Act to regulate greenhouse-gas emissions from vehicles. They also disagreed with the agency's contention that even if it had the authority, it doesn't have to regulate if it doesn't want to.

"The use of the word 'judgment' is not a roving license to ignore the statutory text," wrote Justice John Stevens. "Under the clear terms of the Clean Air Act, EPA can avoid taking further action only if it determines that greenhouse gases do not contribute to climate change or if it provides some reasonable explanation as to why it cannot or will not exercise its discretion to determine whether they do."

Led by Massachusetts, the case was brought by several states, a handful of environmental groups and American Samoa. They argued that climate change was, among other things, causing the sea to rise up and swallow some states' territory and that the EPA was breaking the law by refusing to consider greenhouse gases as 'pollutants', which it has to regulate under the Clean Air Act.

The EPA denied this on a number of grounds, including appealing to the intentions of Congress when creating the act, and the desirability of using the promise of reducing emissions as a lever to force developing countries to do the same - something that wouldn't be possible if the EPA was already regulating them (see Nature 443, 486-487; 2006).

Lead author of the petition for Massachusetts, Lisa Heinzerling of Georgetown University Law Center in Washington DC, is naturally pleased with the outcome: "On every single issue we won, and I think we won big."

The ruling means that the EPA must now evaluate greenhouse gases and determine whether they are "air pollution which may reasonably be anticipated to endanger public health or welfare". If it finds that they are, it must regulate them. But there is no timeline for how quickly it must do this. The EPA under the Bush administration "will not move on it at all", says David Bookbinder, director of climate litigation at environmental group the Sierra Club, who was among the petitioners. "They have 18 months [left], they are a lame duck; they are not interested in climate-change regulation."

It is more likely that the next US president will begin to regulate greenhouse-gas emissions through the Clean Air Act, he says, if Congress doesn't get there first by passing climate-change laws. Certainly, many of the Democrats in Congress would love to regulate emissions in a similar manner to the European Union's Emission Trading Scheme.

Senator Barbara Boxer (Democrat, California), head of the Senate Committee on Environment and Public Works, plans to call EPA officials to Capitol Hill later this month to ask them how they will begin regulating climate change. In a statement, she said: "We now have a two-track process for addressing global warming - comprehensive legislation and administrative action."

The EPA is "reviewing the court's decision to determine the appropriate course of action", says spokeswoman Jennifer Wood, adding that "the Bush administration has an unparalleled financial, international and domestic commitment to reducing greenhouse-gas emissions" - a slightly bizarre contention, to say the least. Emma Marris neuronal pathways that mediate touch sensations. "I moved very quickly to get a material-transfer agreement after we heard Deisseroth talk about the work," he says. "We are really psyched up about it."

But Petersen cautions that the intellectual-property issues surrounding such a significant technology "should be huge". So far, the parties involved are commenting little on the conflicting claims. Deisseroth points out that Boyden was supported by his Stanford lab when the work on NpHR began there. But both claims may have to fight their way round a 1991 patent awarded to Japanese scientists, which broadly covers light-activated channels.

Alison Abbott

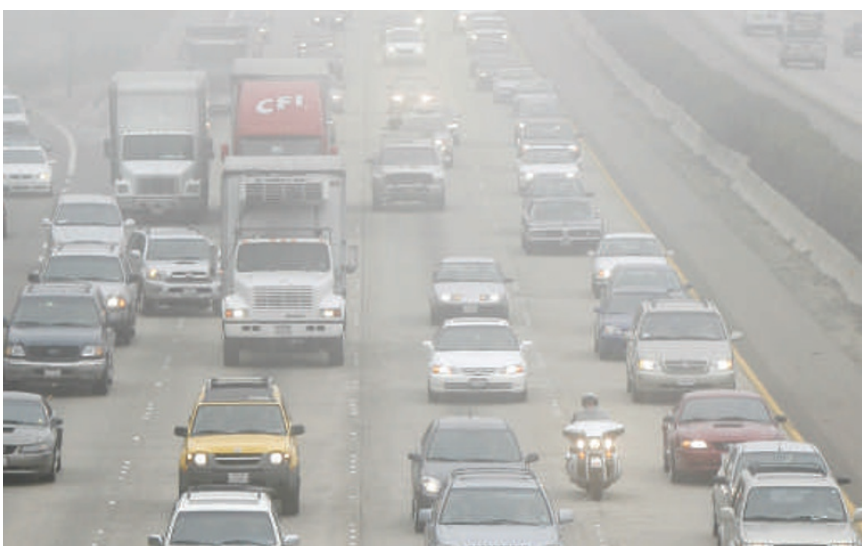

The Environmental Protection Agency now faces the task of regulating greenhousegas emissions from vehicles. 